\title{
26. Profiles of Italy: Localising Practices of Swedish Publishing Houses
}

Cecilia Schwartz

Italian, Stockholm University

Is it possible to pinpoint the status of a foreign literature in a receiving culture? In this chapter, I will briefly suggest a methodological path that can be followed in order to find out more about attitudes towards translated literature, by focusing on the selection of titles and the packaging of books. Why is selection and packaging crucial to the understanding of transnational literary relations?

According to Lawrence Venuti, the translation process is a "localizing practice" that involves a whole series of actions that are "mediated by values, beliefs, and representations in the receiving situation. Far from reproducing the source text, a translation rather transforms it by inscribing an interpretation that reflects what is intelligible and interesting to receptors". ${ }^{\text {I Even though }}$ Venuti mainly pays attention to the discursive strategies performed in the translated texts, he also argues that the process of inscription "operates at every stage in the production, circulation, and reception of the translation". ${ }^{2}$

\footnotetext{
Lawrence Venuti, Translation Changes Everything: Theory and Practice (London, New York: Routledge, 2013), I93.

2 Lawrence Venuti, The Scandals of Translation: Towards an Ethics of Difference (London, New York: Routledge, I998), 67.
}

How to cite this book chapter:

Schwartz, Cecilia. "Profiles of Italy: Localising Practices of Swedish Publishing Houses". In World Literatures: Exploring the CosmopolitanVernacular Exchange, edited by Stefan Helgesson, Annika Mörte Alling, Yvonne Lindqvist, and Helena Wulff, 310-323. Stockholm: Stockholm University Press, 20I8. DOI: https://doi.org/Io.I6993/bat.z. License: CC-BY. 
The suggested analysis takes into consideration the localising practices in the part of the production that does not include the translated texts, but rather some of the actions performed by the publishing houses: the selection and packaging of Italian texts for a Swedish readership. Furthermore, while this perspective is mainly relevant to the understanding of contemporary Italian literature's status in Sweden, it will also shed light on the relations between semi-peripheral literatures ${ }^{3}$ that tend to be overlooked in the studies of world literature. ${ }^{4}$ According to recent statistics, Italian is today the sixth or seventh most translated language into Swedish. ${ }^{5}$ Yet, Italian literature seems rather unheard of except for some worldwide bestselling writers such as Umberto Eco, Roberto Saviano and Elena Ferrante. So what is the overall status of Italian literature in Sweden today? To answer this question, the researcher has to start out with an analysis of Swedish publishing houses specialised in Italian literature.

Publishing houses are crucial gatekeepers when literature travels from one culture to another. In the years 2009-II, no fewer than four publishing houses with special focus on Italian literature were founded in Stockholm. ${ }^{6}$ This peculiar situation - four

3 Gisèle Sapiro, "The sociology of translation. A new research domain", in A Companion to Translation Studies, ed. Sandra Bermann et al. (Chichester: Wiley Blackwell, 20I4), 85 . According to Sapiro, until I989, Italian and Swedish, together with Spanish, Danish, Polish, Russian and Czech, belonged to the happy few in the literary semi-periphery, which means that these languages had a share that varied from one to three per cent of the languages in the world system of translations. After the fall of the Berlin wall, Polish and Czech lost their semi-peripheral position, while Italian, Spanish and Swedish literature remained stable.

4 Cf. Theo D'haen, The Routledge Concise History of World Literature (New York: Routledge, 201 2), I 53.

5 Due to these statistics provided by the National Library of Sweden, Italian was preceded by English, Norwegian, French, German and Danish in 2016 and by the same languages plus Finnish in 2017. Kungliga biblioteket. Nationalbibliografin i siffror 2016 (Stockholm: Nationalbibliografin, Kungliga biblioteket, 20I7), I4-I5; Kungliga biblioteket. Nationalbibliografin $i$ siffror 2017 (Stockholm: Nationalbibliografin, Kungliga biblioteket, 20I8), II.

${ }^{6}$ Cartaditalias bokserie (2009-20I2) was established in the wake of a bilingual cultural magazine, Cartaditalia, both initiatives by the Italian 
publishing houses founded in a two-year-period - raises questions closely related to the status of Italian literature in Sweden:

- Which texts, authors and genres were published by these four newcomers?

- How were these texts and authors presented to the Swedish readership?

- How can an analysis of the selection and packaging contribute to the understanding of the status of Italian literature in contemporary Sweden and of semi-peripheral relations in world literature?

In the following, I will briefly outline a useful methodological path for analysing these four newcomers in the publishing field. First of all, a bibliographical research must be carried out in order to get a panoramic view of the Italian literature published in Sweden in the studied period. ${ }^{7}$ In this specific case, since the publishing houses were all founded in the years 2009-I I, I suggest starting from at least year 2005 and list all Italian titles translated into

Cultural Institute in Stockholm. The house published novels, poetry, essays and short stories of Italy's most prestigious authors (Italo Calvino, Pier Paolo Pasolini, Elsa Morante etc). In $20 \mathrm{IO}$ another publishing house arose, Astor (20IO-20I4), which mainly focused on contemporary literature from the Italian and Spanish language area. Astor published novels, short stories and essays by writers from the younger generation (born in the I970s), who had never been translated into Swedish before. Still in 20I0, another firm with an Italian profile was established in Stockholm, Laurella \& Wallin (2010-20I4). Their idea was to publish texts written in the borderland between fiction and travel literature. All in all, Laurella \& Wallin published eight titles, of which the first five focused on one Italian city each (Palermo, Rome, Florence, Venice and Naples). The only publishing house that has survived until the present day is Contempo, which was founded in 20II by a father and his daughter. As the name chosen for the house indicates, it concentrates on contemporary Italian novels, all very successful in their homeland. Currently they have published I 5 titles.

7 On the importance of making lists and bibliographies, see Anthony Pym, Method in Translation History, (Manchester: St Jerome Publishing, I998), 38-54. 
Swedish up until 20I $5 .{ }^{8}$ This temporal perspective offers a frame for the analysis by mapping the importation of Italian literature into Sweden before and during the rise of these specific publishing houses. It also offers an objective context to which the following steps of the analysis can be related. To complete the picture, a quantitative analysis of optional variables - such as genre, publisher, author's and translator's gender etc. - is needed. Then of course the publications of the four publishers must be compared to the general picture.

However, if we want to consider the publishing houses' selection of titles as a localising practice, it has to be considered from a qualitative perspective, not least of all because the selection is "always an exclusion of other foreign texts and literatures". 9 One factor that is crucial to an analysis focusing on publishing houses is the distinction between big and small publishing houses in the translation field. When it comes to foreign literature, big publishers tend to contribute to standardisation since they prefer traditional novels written in English, while smaller firms rather contribute to innovation by introducing new authors and translating from languages other than English. ${ }^{\circ 0}$ The discovery of new (or ignored) authors, which might lead to true innovation in the literary field, is actually perceived as one of the most important functions of small publishing houses. ${ }^{\text {II }}$ In order to survive in the competition with larger publishers, small firms often concentrate on a niche. One such niche strategy consists in choosing literature from a specific language area, which "explains the role they play in discovering writers in peripheral or semi-peripheral languages". ${ }^{\text {I2 }}$ But what are the consequences of this niche strategy in terms of localising practices? Are the selections made concerning

8 The easiest way would be to make a search on the Nationalbibliografin (Swedish National Bibliography).

9 Venuti, Scandals, 67.

ro Gisèle Sapiro, Translatio: Le marché de la traduction en France è l'heure de la mondialisation (Paris: CNRS Éditions, 2008).

II Sapiro, Translatio, I90.

I2 Gisèle Sapiro, "Translation and the field of publishing. A commentary on Pierre Bourdieu's 'A conservative revolution in publishing', Translation studies I, no. 2 (2008): I 57. 
the source or target culture? Or do the publishers instead rely on the transnational circulation of the chosen literature? And what localising practices are visible in the presentations and packaging of the chosen language area?

In order to answer these questions, the selection of titles can be approached by using different analytical tools. A proficient way is to examine which other languages the selected works have already been translated to. This approach not only contributes to a better understanding of the circulation patterns of semi-peripheral literature, it also tests the legitimacy in Sapiro's statement that "the chance for a work published in a peripheral language to be translated in another peripheral language depends greatly on its

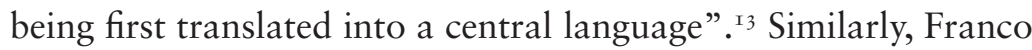
Moretti argues "that movement from one periphery to another (without passing through the centre) is almost unheard of". ${ }^{14}$ Is this assumption confirmed in our case as well? If not, the analysis must go beyond the macro-dimension and focus on other aspects, such as the agents involved in the importation.

The selection of texts could also be perceived as a way of "challenging domestic canons for foreign literatures and domestic stereotypes for foreign cultures", ${ }^{15}$ and on the contrary, the selection could confirm such domestic canons and stereotypes. For instance, if Swedes associate Italy with mafia, then one might expect that publishers specialised in Italian literature will be inclined to relate to this cliché in one way or another. Do they reinforce the cliché or do they try to challenge it by offering alternative perspectives of Italy? ${ }^{16}$

In terms of inclusion it is even more intriguing to compare the titles selected by the foreign publishers with the same titles' status in the national field, since canons of the source literature

\footnotetext{
I3 Sapiro, Sociology, 86.

I4 Franco Moretti, "More Conjectures", New Left Review, 20 (2003): 75.

I5 Venuti, Scandals, 8I.

${ }^{16}$ Cf. Hanne Jansen, "Bel Paese or Spaghetti noir? The image of Italy in contemporary Italian fiction translated into Danish", in Interconnecting translation studies and imagology, ed. by Luc van Doorslaer, Peter Flynn and Joep Leerssen, (Amsterdam: John Benjamins, 20I 5), I63-79.
} 
often differ from the target literature. ${ }^{17}$ Especially in the cases in which the publishing houses make their decisions in close relation to the source culture, it is appropriate to analyse the selected author's position in the source field. A useful tool for conducting this analysis is offered by Sapiro, who distinguishes between four ideal-typic writers: the notables, the aesthetes, the popular and the avant-garde writers. ${ }^{18}$

If the selection is made in a closer relation to the receiving culture or with an international perspective, another appropriate model is suggested by Danielle Risterucci-Roudnicky (2008), ${ }^{19}$ who argues that it is possible to locate every translation in the field by combining two opposing axes: the canonisation-discovery dimension and the distancing-naturalisation dimension, where the latter relies on the ways in which a translation is included in the new system: is the foreignness of a literary work highlighted (distancing) or hidden (naturalisation)? ${ }^{20}$ According to Risterucci-Roudnicky, the place that a translation occupies alongside these axes determines its symbolic position in the editorial landscape: a naturalised canonised title would have a higher symbolic capital than an unknown author's work where the distance from the receiving culture is underscored. ${ }^{2 \mathrm{I}}$ Is this the case

${ }^{17}$ Cf. Mads Rosendahl Thomsen, Mapping World Literature. International Canonization and Transnational Literatures (London: Continuum, 2008).

I8 Gisèle Sapiro, "Le champ littéraire français. Structure, dynamique et formes de politisation", in Art et société. Recherches récentes et regards croisés, Brésil/France, ed. Alain Quemin et al. (Marseille: Open Edition Press, 2016), accessed 23 January 2017, doi: 10.4000/books.oep.475. Even though Sapiro's distinction regards the French literary field, I argue that it could be applied on many other national fields. In the case of Italian literature, it is particularly appropriate since the boundaries between the French and the Italian literary fields are very strong.

I9 Danielle Risterucci-Roudnicky, Introduction à l'analyse des ouvres traduites (Paris: Armand Colin, 2008).

20 See also Lawrence Venuti's discussion on foreignising and domesticating translations in The Translator's Invisibility: A History of Translation (London, New York: Routledge, 2008).

2г Risterucci-Roudnicky, Introduction, I 8. 
in a semi-peripheral culture as well? Or could the underscored foreignness - for instance in the packaging - be a way to gain symbolic capital?

Another method is put forward by Sapiro. Drawing on Bourdieu, she has elaborated a model for analysing translated literature that can be applied to the selection in order to find out about the criteria used more or less deliberately by the publishers when choosing titles for translation. ${ }^{22}$ Suggesting how works translated into French can be classified, the method combines a vertical depoliticised-politicised axis with a horizontal axis that goes from the particular (left) to the universal (right). By crossing these two axes, four different categories, in which the selected titles can be inserted and roughly classified, are distinguished:

Depoliticised particularism: This dimension is particularly strong when it comes to the selection of foreign literature, as it focuses on the ethnographic dimension of culture and often balances on the edge of exoticism.

Depoliticised universalism: literary texts marked by individualism, subjectivism and formalism. By expressing a subjectivity that can be shared over time and space these works inscribe themselves into the "universal" literature - the classics. In this category, Sapiro inserts the catalogues of a prestigious publisher such as Gallimard as well as many smaller highbrow publishers.

Politicised universalism: Even though this category includes works that are conceived as universal, it differs from the former as it features the historical and moral dimension of literature. Although these works are often believed to grasp the universal from the particular, as for instance in memoirs and ethical world fiction, they dissociate from exoticism and identity politics by encouraging hybrid identities.

Politicised particularism: When the socio-political dimension is combined with the particular identity dimension, we find a category of works defined as identity political. These are narratives in which the author's identity is crucial and where the cultural particularity, as well as the political or social dimension, is privileged.

22 Sapiro, Translatio, 204-9. 
When applying this model, the researcher must be aware of the fact that it is a description of translations into French during the years I984-2002. Obviously, not only the dimensions are likely to differ from one literature to another (and from one time to another), but there will always be works that do not fit into such schematic representations. ${ }^{23}$ This brings us to the next step in the analysis, which takes into account more concrete signs of localising practices visible in the surroundings of the literary text, the paratext.

In his seminal work Seuils, ${ }^{24}$ Gérard Genette outlines a theory of the paratext, which includes all the elements that accompany the literary text: covers, titles, the author's name, notes, prefaces, interviews with the author etc. According to Genette, the concept of paratext should be conceived as an umbrella term that is bifurcated into two main areas: the peritext and the epitext. The elements of the peritext are more closely related to the text per se - prefaces, titles, titles of the chapters, footnotes, covers, blurbs - while the epitext addresses all the messages outside the actual volume, such as interviews with the author, private conversations, letters, diaries etc. Genette mainly focused on literary works in their original language, and the theory has only recently been adapted to the area of translated literature, where much remains to be done. ${ }^{25}$

${ }^{23}$ However, in the case of the four "Italian" publishing houses it seems that the selection could be inserted in all categories described above, except one, the politicised particularism. This suggests that publishing houses with an Italian focus deliberately exclude postcolonial narratives from their catalogues.

${ }^{24}$ Gérard Genette, Seuils (Paris: Seuil, I987). Translated by Jane E. Lewin as Paratexts. Thresholds of interpretation (Cambridge: Cambridge University Press, I997).

25 Until now only a few volumes that combine the paratextual perspective with the translational to any lengthier extent have been published: Richard Watts, Packaging Post/coloniality: The Manufacture of Literary Identity in the Francophone World, (2005), Danielle RisterucciRoudnicky, Introduction à l'analyse des ouvres traduites, (Paris: Armand Colin, 2008); Anna Gil-Bardají et al. (eds.), Translation peripheries: Paratextual Elements in Translation (Bern: Peter Lang, 2012); Chiara Elefante, Traduzione e paratesto, (Bologna: Bononia University Press, 
I would argue that when it comes to translated works, an analysis of the paratext is even more relevant than it might be for source texts. Why is that? Generally, it has to do with the mediating role performed by paratextual items in the transmission of literary texts between cultures. Paratexts represent bybrid spaces where source and target cultures meet. ${ }^{26}$ Since the current research task concerns the status of Italian literature in present Sweden, an analysis of the localising practices performed by the publishers is required: to what extent do the publishers remain faithful to the source edition, and to what extent do they adapt the surroundings of the text to the receiving culture? Focusing on the publisher's paratext reveals motives for publishing a certain text as well as suggestions on how to read and use the volume: the paratext invites the reader to share the publisher's own interpretation of the text, ${ }^{27}$ and at the same time it designs and defines the publishing houses' target readers.

Even though the most intriguing part of the paratext, at least for the purpose of the research task presented here, concerns the publisher's peritext (and especially covers, titles, prefaces and notes), a proficient starting point would be to examine the publisher's epitext, i.e. presentation texts on the website, interviews and articles in the press in order to trace the publishers' profile and self-perceived function in the Swedish field. ${ }^{28}$ This first step of

2012), Valerie Pellatt (ed.), Text, Extratext, Metatext and Paratext in Translation (Cambridge: Cambridge Scholars Publishing, 2013). For studies on translation and paratexts with a particular attention given to the Swedish literary field, see Jerry Määttä, Raketsommar. Science fiction $i$ Sverige 1950-1968 (Lund: Ellerströms) and Cecilia Alvstad "The Strategic moves of Paratexts: World Literature through Swedish Eyes”, Translation Studies, 5 (I) (2012): 78-94.

${ }^{26}$ Cf. Risterucci-Roudnicky, Introduction, 30.

${ }_{27}$ Alberto Cadioli, "Il patto editoriale nelle edizioni moderne e contemporanee", in I dintorni del testo. Approcci alle periferie del libro, ed. Marco Santoro et al. (Rome: Edizioni dell'Ateneo, 2005), 664. According to Alberto Cadioli, the very edition of a literary text reflects the publisher's intention to establish a pact with the reader, "il patto editoriale" ("the publisher's pact").

${ }^{28}$ If the analysis considers contemporary publishers, the researcher can contact them in order to carry out interviews. An example of such a 
the analysis would clearly indicate the publisher's view on Italian literature. Following Sapiro, other aspects that should be taken into consideration in the publisher's epitext are statements regarding innovation and tradition, language areas and niche strategies. This part of the analysis will contribute interesting facts about the publishers' own analysis of the sector and their choice to focus on Italian writers in that particular moment.

However, the publishers' localising efforts are mainly visible in the peritext. The elements of the cover and its appendages have been thoroughly listed by Genette. ${ }^{29}$ Among these, the localising practices are most explicit in the translation of the title (see below), in the choice of pictures, photos or other iconographic illustrations, and in the texts on the back cover as well as on the inside front and back covers, where presentations of the author and the intrigue share the space with blurbs and other promotional statements. All these items, which reflect the publishers' attempts to address a certain readership and to express an interpretation of the text, are likely to become revealing representations of the source culture.

The title, which Adorno once addressed as "the microcosm of the work", $3^{\circ}$ has been studied from various perspectives and disciplines. Linguists, for instance, have underscored the function of the determinative article in book titles, while others might have concentrated on the nominal style or the numbers of words used for the title. From a paratextual point of view, the title, being a compromise between the author, the translator and the publisher, is a hybrid space that lends itself to comparison between the source edition and target editions in different languages. What happens, for instance, when Valeria Parrella's novel Lo spazio bianco ("The white space") is translated into German (Zeit des Wartens, "Time

case study is Andreas Hedberg's article "Small Actors, Important Task: Independent Publishers and their Importance for the Transmission of French and Romance Language Fiction to Sweden Since the Turn of the Millennium”. Moderna Språk, I Io, no. 2 (20I6): 2 I-30.

29 Genette, Paratexts, 23-26.

${ }^{\circ}$ Theodor W. Adorno, Notes on Literature (New York, Oxford: Columbia University Press, I992), 4. 
of waiting"), French (Le temps suspendu, "The suspended time") and Swedish (Väntrum, "Waiting room")? Well, it is significant that while the French and German titles emphasise the temporal aspect, the Swedish title remains more faithful to the spatial dimension in the Italian original, but on the other hand the Swedish title concretises the somewhat elusive Italian title, which is better preserved in the French and German variants. This is just one illustration of how localising practices become visible in the paratext, and we could go on by analysing the presence and functions of footnotes and pre- and postfaces, not to mention the publisher's choice of the preface writer. ${ }^{3 \text { I }}$ Genette defines several functions of these peritextual elements, which he basically divides into the themes of the why and the themes of the how. ${ }^{32}$ When translated works eventually contain a translator's preface, Ellen McRae has shown that in a corpus of contemporary fiction translated into English, the main functions of the translator's fore- or afterword were to call for the reader's attention to the translator's role, as well as to promote a mutual understanding between cultures. ${ }^{33}$

\section{Concluding remarks}

The research task proposed in this chapter draws on the conviction that current ideas of Italian literature and its overall status in present Sweden are manifested in the publishing houses' localising practices, which are expressed in the selection of titles as well as in paratexts. However, depending on the aim of the research task, the presented methods and models might be used together or separately, on similar material.

${ }^{31}$ For instance, Ulf Norberg argues that in Sweden, "the writers of prefaces usually have a large literary capital (literary critics, literary scholars or authors)". Translation peripheries, ed. Anna Gil-Bardají (Bern: Peter Lang, 201 2), I05.

32 Genette, Paratexts, I98-223.

33 Ellen McRae, “The role of translators' prefaces to contemporary literary translations into English: An empirical study", in Translation Peripheries: Paratextual elements in translation, ed. Anna Gil-Bardají et al. (Bern: Peter Lang, 20I2), 8 I. 
The methods presented in this brief chapter are only samples of the resources that are available for a researcher today. It is important to keep in mind, though, that most of the existing models originate from the Anglo-American and French-speaking areas, which might not be adequate for describing the situation in semi-peripheral or peripheral language areas. As researchers we must therefore presume that the overall picture might differ from one literature to another and from one time to another. From this we can draw the intriguing and stimulating conclusion that methods that are better suited for describing (semi-)peripheral relations need to be elaborated and developed if we want to obtain a deeper understanding of neglected areas of world literature.

\section{Bibliography}

Adorno, Theodor W. Noten zur Literatur. Frankfurt am Main: Suhrkamp Verlag, I974. Translated by Shierry Weber Nicholsen as Notes on Literature. New York, Oxford: Columbia University Press, I992.

Alvstad, Cecilia. "The Strategic moves of Paratexts: World Literature through Swedish Eyes". Translation Studies 5, no. I, (20I 2): 78-94.

Cadioli, Alberto. "Il patto editoriale nelle edizioni moderne e contemporanee". In I dintorni del testo. Approcci alle periferie del libro, vol. II, edited by Marco Santoro and Maria Gioia Tavoni, 663-672. Rome: Edizioni dell'Ateneo, 2005.

D'haen, Theo. The Routledge Concise History of World Literature. London, New York: Routledge, 2012.

Elefante, Chiara. Traduzione e paratesto. Bologna: Bononia University Press, $20 \mathrm{I} 2$.

Genette, Gérard. 1987. Seuils. Paris: Editions du Seuil. Translated by Jane E Lewin as Paratexts: Thresholds of Interpretation. Cambridge: Cambridge University Press, 1997.

Gil-Bardají, Anna, Pilar Orero, and Sara Rovira-Esteva, eds. Translation Peripheries: Paratextual Elements in Translation. Bern: Peter Lang, 20I 2. 
Hedberg, Andreas. "Small Actors, Important Task: Independent Publishers and their Importance for the Transmission of French and Romance Language Fiction to Sweden Since the Turn of the Millennium”. Moderna Språk, I Io, no. 2 (2016): 2 I-30.

Jansen, Hanne. "Bel Paese or Spaghetti noir? The Image of Italy in Contemporary Italian Fiction Translated into Danish". In Interconnecting Translation Studies and Imagology, edited by Luc van Doorslaer, Peter Flynn and Joep Leerssen, I 63-79. Amsterdam: John Benjamins Publishing, 2015.

Kungliga biblioteket. Nationalbibliografin i siffror 2016 . Stockholm: Nationalbibliografin, Kungliga biblioteket, 2017.

Kungliga biblioteket. Nationalbibliografin i siffror 2017. Stockholm: Nationalbibliografin, Kungliga biblioteket, 20 г 8.

McRae, Ellen. “The Role of Translators' Prefaces to Contemporary Literary Translations into English: An Empirical Study”. In Translation Peripheries: Paratextual Elements in Translation, edited by Anna Gil-Bardají, Pilar Orero and Sara Rovira-Esteva, 63-82. Bern: Peter Lang, $20 \mathrm{I} 2$.

Moretti, Franco. "More conjectures”. New Left Review 20 (2003): 73-8I.

Määttä, Jerry. Raketsommar. Science fiction i Sverige I950-I968. Lund: Ellerströms, 2006.

Norberg, Ulf. "Literary translators' comments on their translations in prefaces and afterwords: the case of contemporary Sweden". In Translation Peripheries: Paratextual Elements in Translation, edited by Anna Gil-Bardají, Pilar Orero and Sara Rovira-Esteva, IOI-I6. Bern: Peter Lang, 20 I 2.

Pellatt, Valerie, ed. Text, Extratext, Metatext and Paratext in Translation. Cambridge: Cambridge Scholars Publishing, 2013.

Pym, Anthony. Method in Translation History. Manchester: St Jerome Publishing, 1998.

Risterucci-Roudnicky, Danielle. Introduction à l'analyse des œuvres traduites. Paris: Armand Colin, 2008. 
Rosendahl Thomsen, Mads. Mapping World Literature: International Canonization and Transnational Literatures. London: Continuum, 2008.

Sapiro, Gisèle, ed. Translatio: Le marché de la traduction en France à l'heure de la mondialisation. Paris: CNRS Éditions, 2008.

- "Translation and the Field of Publishing. A Commentary on Pierre Bourdieu's 'A Conservative Revolution in Publishing'”. Translation studies I, no. 2 (2008): I 54-66.

. "The Sociology of Translation. A New Research Domain”. In A Companion to Translation Studies, edited by Sandra Bermann and Catherine Porter, 82-94. Chichester: Wiley Blackwell, 2014. . "Le champ littéraire français. Structure, dynamique et formes de politisation”. In Art et société. Recherches récentes et regards croisés, Brésil/France, edited by Alain Quemin and Glaucia Villas Bôas. Marseille: Open Edition Press, 2016.

Venuti, Lawrence. The Translator's Invisibility: A History of Translation. 2nd ed. London, New York: Routledge, 2008.

- The Scandals of Translation: Towards an Ethics of Difference. New York: Routledge, I998.

- Translation Changes Everything: Theory and Practice. New York: Routledge, 20I3.

Watts, Richard. Packaging Post/coloniality: The Manufacture of Literary Identity in the Francophone World. Lanham: Lexington Books, 2005. 